\section{Scientific Research Organisation in Great Britain}

IN the first A. D. Little Memorial Lecture, "Science, Industry and Government", now published in Technology Review (February 1947), Sir Edward Appleton, speaking before an American audience, reviewed British experience in the organisation of research. Success in the organisation of science in the war effort has led the public to conclude that science should play a similar part in solving the problems of peace. Ultimately the provision of work, homes, food, health and safety from aggression for all depend for solution on the maintenance of the same kind of partnership between government, science and industry which grew up during the War; and, referring to the brilliant team-work during the War, Sir Edward pointed out that the result of the policy pursued was that the research establishments of the Services were strengthened by the addition of many brilliant minds from the universities, while the research teams in industry were left intact and ready to attack, as composite units, the problems allotted to them. One of the most striking results of war-time experience in Britain was the brilliant success of university research workers in solving war problems entirely remote from their peace-time interests. University conditions appear to ensure the maintenance of the mental adventurousness and lively imagination so necessary for scientific progress; and in planning the future of the Scientific Civil Service in Britain, an attempt is being made to secure conditions that encourage these qualities.

The most successful applications of science in our war-time experience resulted from the closest possible collaboration between the men of science and the military staff ; the field in which the scientific worker can usefully operate extends far beyond the labora. tory. Free fundamental research had, however, been almost entirely in abeyance in Britain, and we must recognize the return of peace by changing our priorities. In many fields, we have been living on our scientific capital, which now stands urgently in need of replenishment. Pointing out that scientific research in the universities is of relatively modern growth, Sir Edward referred to the accepted university tradition that teachers of scientific knowledge should also advance that knowledge. Although carried out in a spirit of pure inquiry, this free fundamental research has shown a surprising capacity for being useful. The universities are also the source of the trained scientific workers for university, government and industrial laboratories, and in this connexion Sir Edward referred to the outstanding importance of the exceptional man. Most of the really great advances in science have been accomplished by small teams of workers led by a man with ideas, and Sir Edward believes that a vital task is to see that such men lack neither disciples, assistants nor equipment.

\section{Magnetic Recording of Sound}

A LeCTURE on "Developments in Magnetic Recording" was given by Mr. P. T. Hobson to the British Sound Recording Association on March 27, with demonstrations of the wire-recording machine now in produetion and available in small quantities for non-entertainment purposes. A model of a highgrade instrument shows that the technique of wirerecording has risen so rapidly in recent years that the quality of reproduction obtained can be classed as high, if not higher, than with the best disks and the Philips-Miller system. The comparative cheapness of the wire, the possibility of erasure and the immediate rewind makes magnetic recording attractive for many purposes, apart from the straight and protracted reproduction of music. Ever since Poulsen discovered the possibility of magnetic recording nearly fifty years ago, designers have been misled by the erroneous idea of the exact process of magnetization. Research by the Armour Corporation of the United States and also in Britain has led to the selection and heat-treatment of the steel wire so that a diameter of only 4 mils and a velocity of 24 in. a. second can give high-quality reproduction with a signal-to-noise ratio of some 60 decibels. The material is a stainless steel, heat-treated with a current to bring it into the austenitic condition, and with a maximum ratio of the coercive force to remanence, this being the condition for minimizing the almost complete self-demagnetization of the disk-like magnets of which the wire seems to be comprised at the highest frequencies and shortest wave-lengths with tolerable loss.

Mr. Hobson gave an exposition of the theory of such longitudinal magnetization and explained the great advantage of polarizing the magnetizing current with a large component of high carrier-frequency current, which is also used for erasing. The standard machines use reels for recording for a total of 66 minutes, but sufficient quality is left at lower speeds for a total time of eight hours. The non-entertainment machine can run at various speeds for transmitting or receiving high-speed alternating-current signals, while the proposed music-machine not only uses a capstan on which ordinary disks can be played, but also includes an ingenious mechanism which automatically wraps the wire round the capstan for recording or reproducing from wire, thus making the machine substantially foolproof. If the wire should break, a knot can be tied in it.

\section{Research in the South Pacific Area}

AN important outcome of the South Seas Conference at Canberra, January 28-February 6, 1947, attended by delegations representing the Governments of Australia, France, the Netherlands, New Zealand, Great Britain and the United States, which administer non-self-governing territories in the South Seas, was the signing of an agreement establishing the South Pacific Commission, which will seek to promote the economic and social welfare and advancement of two million people in the South Pacific. The Commission is to appoint an advisory research council of persons distinguished in fields of research within the competence of the Commission, including some full-time appointments of persons highly qualified in the fields of health and economic and social development, together with a full-time director of research. The functions of the research council include the maintenance of a continuous survey of research needs in the territories within the scope of the Commission, and making recommendations to the Commission on research to be undertaken; arranging for the prosecution of research studies approved by the Commission, using existing institutions where appropriate and feasible; and co-ordinating the research activities of other bodies working within the field of the Com. mission's activities, and availing itself, where possible, of the assistance of such bodies. The council may also appoint technical standing research committees 
to consider problems in particular fields of research, and, with the approval of the Commission, ad hoc research committees to deal with special problems.

\section{Grading of Scientific Films}

A memorandum on "The Classification, Appraisal and Grading of Scientific Films" issued by the Scientific Film Association, 34 Soho Square, London, W.1, has been drawn up by the Association after consultation and discussion with interested bodies in Britain and in other countries. It is primarily concerned with films of scientific interest for adult audiences; but the method of appraising and grading recommended should be applicable to all types of documentary films. A specimen card on which it is recommended the content and lay-out of the data concerning each film should be standardized is appended, together with a definition of terms commonly used in a special sense by the film industry and film critics. Notes are included on the synopsis of the content of each film, which should be brief and objective, as well as on the determination of accuracy and comprehensiveness within the terms of reference laid down by the producer and with reference to the purpose of the film, while the grading of the film in relation to the types of audience likely to see it is considered separately. The organisation of the viewing panel, the appraisal group meetings, the appraisal stunding committee and the records to be kept are dealt with in the next section, which includes a specimen viewers' report form. The Association hopes that the principles suggested here will be applied wherever films are appraised. It has earned the gratitude of scientific workers who may need to use such films, as a step towards a standard procedure for film documentation which, if accepted internationally, would be of immense value to all who make or use educational films.

\section{Journal of Glaciology}

The Association for the Study of Snow and Ice, formed in 1936, has grown into the British Glaciological Society, which this year has started the publication of the Journal of Glaciology. There is room for such a publication not only to produce the papers read before the Society itself but also to consider many practical aspects of snow and ice. Without undue overlapping, it is clearly desirable to make contacts with various aspects of geomorphology, meteorology and geography. The Journal (price $7 s .6 d$.) is under an editorial committee consisting of Messrs. G. Seligman, W. L. S. Fleming, B. Roberts and R. Moss, and its present address is care of the Royal Geographical Society, London, S.W.7. The first number has varied contents following an introductory note by Prof. H. W. Ahlmann. Mr. G. Seligman explains Dr. R. Streiff-Becker's theory of extrusion flow in glaciers, and the Rev. W: L. S. Fleming discusses some of the Antarctic glaciological researches of Byrd's Third Antarctic Expedition. There are also a number of short articles and the first instalment of a list of recent glaciological publications, in the main non-polar works. The Journal promises to find a place among scientific periodicals of value.

\section{U.S. Chemical Corps Advisory Committee}

AT the request of Major-General Alden H. Waitt, chief of the U.S. Chemical Corps, an advisory committee has been appointed to serve as a liaison group between the Corps and the chemical profession and industry, and to provide advice on scientific and personnel matters in connexion with Chemical Corps research and development. The committee is as follows : Dr. W. Albert Noyes, jun., president of the American Chemical Society and head of the department of chemistry in the University of Rochester (chairman); Prof. R. Adams, University of Illinois ; Prof. A. C. Cope, Massachusetts Institute of Technol. ogy; Colonel Bradley Dewey, of Cambridge, Mass., formerly U.S. Rubber Administrator; Dr. Willard H. Dow, president and chairman of the Dow Chemical Co., Midland, Mich.; Prof. Vincent du Vigneaud, Cornell University Medical College; Prof. Louis F. Fieser, Harvard University; Dr. Per K. Frolich, co-ordinator of research of Merck \& Company, Rahway, N.J. ; Prof. H. F. Johnstone, University of Illinois; Sidney D. Kirkpatrick, chairman of the American Section of the Society of Chemical Industry; Dr. Walter Kirner, director of the Chemical and Biological Coordination Center of the National Academy of Sciences; Dr. Stanford Moore, Rockefeller Institute for Medical Research; R. L. Murray, vice-president and technical director of the Hooker Electrochemical Co., Niagara Falls, N.Y.; Prof. Charles C. Price, Notre Dame University; Prof. Glenn T. Seaborg, University of California; Prof. Harold C. Weber, Massachusetts Institute of Technology ; and Dr. Robert E. Wilsqn, chairman of the board of directors of the Standard Oil Co. of Indiana.

\section{Chinese Fisheries}

AFter many years of devastation China is now, with the help of the United Nations, endeavouring to bring about the rehabilitation of her basic industries. Not least in importance is the fishing industry, and a Chinese Fisheries Research Institute has been formed for the purpose of carrying out investigations necessary to guide the Chinese fisheries industry during the difficult period of the immediate future and to provide data upon which to base enlightened fisheries administration. Implementation of this programme is severely hampered by lack of books and equipment, and an appeal has been launched for donations of any suitable books, journals and other periodicals that individuals or institutions may be able to spare. As the Institute possesses little more than a measuring-board in the way of equipment, donations of scientific apparatus will also be welcomed. All gifts and offers of help should be sent to the Director, Fisheries Research Institute, Room 402, National City Bank Building, 54 Kiukiang Road, Shanghai, China.

\section{Quality Control Methods in Canada}

A specrar committee has just been established by the National Research Council of Canada to promote the application of mathematical methods in the trieatment of certain industrial production problems. Members of the committee include specialists in statistical quality control procedures, in sampling surveys, in the design of experiments, and in biometry or the statistical study of variation; the chairman is Dr. J. W. Hopkins, National Research Council, Ottawa. The committee will assist Canadian users of mathematical statistical methods by consultation and advice respecting specific technical problems; it will also support research in this field by qualified workers, and provide a means of liaison with technical groups in Canada and abroad. 